\title{
Food Crisis and Export Taxation: Revisiting the Adverse Effects of Noncooperative Aspect of Trade Policies
}

\author{
Antoine Bouët and David Laborde Debucquet
}

\subsection{Introduction}

Export restrictions are a common practice in the current world trading system. For instance, some developing countries implemented export taxes and export restrictions during the recent food crisis (2006-2008). But beyond crisis periods, export restrictions are, in fact, trade measures that are permanently adopted by some countries: export taxes implemented by Indonesia on palm oil; by Madagascar on vanilla, coffee, pepper, and cloves; by Pakistan on raw cotton; by the Philippines on copra and coconut oil; and by Argentina on crops and meat.

At a first glance, from a mercantilist point of view, it might be difficult to understand why countries implement so many export restrictions. Indeed, policymakers tend to favor exports and discourage imports. However, a more thorough analysis revealed several justifications.

In this chapter, we consider these justifications and study how export taxation may worsen a food crisis. It is important to keep in mind that reducing import duties may also amplify food crisis and that these policy options form the basis of an asymmetric game.

\footnotetext{
A. Bouët $\bullet$ D. Laborde Debucquet $(\bowtie)$

International Food Policy Research Institute (IFPRI), Washington, DC, USA

University of Bordeaux, Bordeaux, France

e-mail: a.bouet@cgiar.org 
We also focus on institutional aspects and, in particular, why export taxes can be so easily raised. It appears that countries have a considerably large degree of freedom when implementing such taxes as the WTO does not prohibit export taxes and other forms of export restrictions. As stated by Crosby (2008), "general WTO rules do not discipline Members' application of export taxes," but "they can agree - and several recently acceded countries, including China, have agreed-to legally binding commitments in this regard." The Uruguay Round Agreement on Agriculture only stipulates that, when implementing a new export restriction, a WTO member must (1) consider the implications of these policies on food security in importing countries, (2) give notice to the Committee on Agriculture, and (3) consult with WTO members that have an interest. The agreement does not institute any penalty for countries ignoring the rules. Restrictive export policies do not receive much attention from the public or the academic establishment.

Section 8.2 provides the various justifications for export restrictions. Section 8.3 investigates the role of export taxes in worsening a food crisis. Section 8.4 focuses on the limited institutional role of WTO in the topic of restrictive export policies. Section 8.5 concludes this chapter.

\subsection{Why Do Countries Implement Export Restrictions?}

Before discussing the policy justifications for export restrictions, it is noteworthy that, from a theoretical point of view, export taxes and export quotas are equivalent: quotas could raise revenue if quota allocations are not issued for free but auctioned under competitive conditions. However, in the real world, export licenses are given to domestic producers and do not generate public revenue. Therefore, export taxes and export quotas are not equivalent in the real world. ${ }^{1}$

The first justification is the terms-of-trade argument and the desire to increase export prices. This is perhaps the most important justification from a theoretical point of view. By restricting its exports, a country that supplies a significant share of a commodity to the world market may raise the world price of that commodity. This implies an improvement in that country's terms of trade. The reasoning behind this argument is very similar to the optimum tariff argument, which states that, by implementing a tariff on its imports, a "large" country can significantly decrease the demand for a commodity that it imports; this therefore leads to a decrease in the commodity's world price, which is again an improvement in the terms of trade (Bickerdike 1906; Johnson 1953).

When considering the final consumption of food products, the second justification is food security: export taxes reduce domestic prices. When considering a food product which is an important commodity in a country's national consumption

\footnotetext{
${ }^{1}$ Let us mention that export quota and export taxes are also not equivalent under retaliation, that is to say if implemented during a trade war between large countries (see Rodriguez 1974; Tower 1975).
} 
structure and is also exported, by imposing an export tax, a government creates a wedge between the world price and the country's domestic price. This can lower the final domestic consumption price by reorienting domestic supply toward the domestic market. Piermartini (2004) cited the Indonesian government as an example. The Indonesian government frequently imposes export taxes on palm oil products, in particular on palm cooking oil, as it considers cooking oil an "essential commodity" for local households. This rationale was often used by governments during the food crisis of 2006-2008 to justify implementing export taxes and other forms of export restrictions. Some examples of which are as follows: Bangladesh, Brazil, Cambodia, China, Egypt, and India implemented restrictive policies on rice and Argentina, India, and Kazakhstan on wheat. Export restrictions are anticyclical trade policy instruments: when international prices are high, local consumers are hurt by high domestic prices; implementing export restrictions decreases local prices but contributes to the rise of international prices.

The third justification takes into account the existence of intermediate consumers (firms) of the taxed products in a country. If a raw commodity is exported and is also used by the local processing industry, imposing export taxes on this primary commodity indirectly subsidizes the local processing industry by lowering the domestic price of inputs compared to the commodity's world price, which is nondistorted. It has the same mechanism as the previous reason: export taxation gives local producers more incentive to sell their product domestically. For example, in Indonesia, an export tax on lumber promoted the development of the domestic wood-processing industry; the development was judged to be excessive for environmental reasons as it contributed to the depletion of forests (World Bank 1998). In 1988, Pakistan imposed an export tax on raw cotton in order to stimulate the development of the yarn cotton industry. Export taxes on palm oil are imposed in Indonesia and Malaysia to support the development of downstream industries (biodiesel and cooking oil; see Amiruddin 2003). According to this line of reasoning, export taxes may also be applied to a whole value chain by decreasing the level of taxation along the value chain. This is called differential export tax (DET) rates: the policy of imposing high export taxes on raw commodities and low export taxes on processed goods. This policy generates public revenues and promotes production at the later stages of a value chain. Bouët et al. (2014) studied the theoretical justification of this trade policy, and then they developed a partial equilibrium model of the global oilseed value chain and simulated the total elimination of DETs in Argentina and Indonesia and the independent removal of export taxes at various stages of production in the two countries. Their estimations showed that removing export taxes along the entire value chain in Argentina and Indonesia reduced the local biofuel production; they also point out that the DETs were implemented to raise public revenues.

The fourth justification is also a "raison d'être" for export taxes. Export taxes provide a source of revenue to developing countries that have limited capacity to rely on domestic taxation. This is a second-best argument because the imposition of lump-sum taxes is a first-best policy (Ramsey 1927; Diamond 1975). It is noteworthy that only export taxes (and not export quotas) serve this objective. 
As with all trade policy, export taxes may serve the purpose of redistributing income. This is the fifth justification of this policy instrument combining different aspects from the three previous arguments. Like import tariffs, export taxes are measures that imply distribution of income. Here, this is detrimental to domestic producers of the taxed commodity but benefits domestic consumers and public revenues.

So we arrive at the first conclusion: export taxes are attractive policy instruments since they may serve different positive purposes for a government.

This is the reason why export taxes are relatively common in the current global trading system. Some studies have estimated their importance. Laborde et al. (2013) used a new detailed global data set on export taxes at the HS6 level and the MIRAGE global CGE model to assess the impact of export taxes on the world economy. They found that the average export tax on global merchandise trade was $0.48 \%$ in 2007, with the bulk of these taxes imposed on energy products. Moreover, the removal of these taxes would increase global welfare by $0.23 \%$, a larger figure than the gains projected by the Doha Round. Both developed and emerging economies, such as China and India, would gain from removing export taxes. Medium and small food-importing countries without market power (such as the least-developed countries) would also benefit from the elimination of export restrictions. The export taxes implemented by the countries in the Commonwealth of Independent States on their energy sector appear to play a critical role in the overall economic impact of the removal of these taxes. However, some countries, such as Argentina, would experience income losses.

In the next section, we focus on using food security as a justification for export taxation. We show how implementing this policy instrument is a noncooperative trade policy when food prices are high. During a food crisis, governments of foodexporting countries are tempted to alleviate high food prices by restricting exports to encourage local producers to sell food items domestically and decrease local prices. But in doing so, these countries decrease the food supply on the world markets, causing world food prices to increase. This worsens the food crisis and is typically a "beggar-thy-neighbor" policy.

But in times of food crisis, restricting exports is not the only noncooperative trade policy. Food-importing countries are, at the same time, tempted to decrease domestic food prices by decreasing import duties. In doing so, they increase their national demand on the world market, reinforcing the upward pressure on world food prices. This is another noncooperative aspect of trade policies in periods of food crisis.

The combination of export taxes and reduced import duties increases the upward pressure on world prices when food prices are high. On the contrary, when world agricultural prices are low, food-exporting countries may be tempted to decrease export taxes and food-importing countries to increase import duties. This increases food supply and reduces food demand on world markets and therefore once again increases the downward pressure on world prices. It may appear that trade policies make world markets structurally more volatile. 


\subsection{To What Extent Does Export Taxation Amplify Food Price Volatility?}

Economic literature helps to explain why large food-exporting countries implement export taxes and large food-importing countries implement import duties. The first reason is terms of trade. Bouët and Laborde (2012) designed a general equilibrium model of international trade between four countries-two large (1 and 2) and two small (3 and 4) — which trade the two commodities A (agricultural commodity) and I (industrial good). Countries 1 and 4 have a comparative advantage in A, while countries 2 and 3 have a comparative advantage in I. Import duties on the industrial good are assumed to be bound at 0 , which implies that countries 1 and 4 will not use this policy instrument.

Using this simple framework, it is easy to show that if governments' objective is to maximize real income (welfare), the Nash equilibrium is a combination of a positive import duty in country 2 (the large food-importing country) and a positive export tax in country 1 (the large food-exporting country), while free trade is the best policy for both small countries. The results point out that large countries may manipulate world prices by imposing import duties or export taxes, depending on their export status. This Nash equilibrium implies a reduction in world real income, but large countries may benefit by having augmented real income. It is important to note that an import duty in the large food-importing country tends to decrease the world price of the agricultural commodity, while an export tax in the large foodexporting country tends to increase it. If at the Nash equilibrium, the world price of this commodity is increased, the small food-importing country's real income is reduced, while the small food-exporting country's real income is augmented. This teaches us that (1) export taxes on agricultural commodity improves terms of trade of large food-exporting countries and (2) when combined with import duties in large food-importing countries, world trade is drastically reduced and world real income is hurt with no policy option for small countries.

Bouët and Laborde (2012) also showed that if a government's objective is to achieve stable domestic agricultural goods prices during a food crisis, the best response is to decrease import taxes for a large food-importing country and to increase export taxes for a large food-exporting country. Both policies increase the world price of agricultural goods, thereby hurting a small food-importing country while increasing a small food-exporting country's real income.

Consequently, a collective action problem emerges from this simple theoretical framework: in case of a food price spike, governments which are concerned with establishing domestic food security and stabilizing domestic food prices are tempted to reduce import duties on food items if they are food importers and to increase export taxes on food items if they are food exporters. Both policy reactions tend to reinforce the increase in food world prices. Martin and Anderson (2012) also pointed out this inefficiency. Gouel (2014) designed a simple stochastic partial equilibrium model and concluded that countercyclical trade policies are inefficient 
at the global level: these trade policies increase world prices when the prices are relatively high, while they reduce world prices when the prices are relatively low. ${ }^{2}$

How much these trade policies amplify world price spikes remains to be known. In the same paper, Bouët and Laborde (2012) used the MIRAGE model of the world economy to evaluate this point. The study uses the static version of MIRAGE under perfect competition with 27 regions and 25 sectors. ${ }^{3}$ They simulated a demand shock which led to a $10 \%$ increase of the world wheat price. In the first policy scenario, countries that are net wheat exporters implement export taxes such that the real domestic price of wheat is constant. This led to additional export taxes in the range of 16-25\%. This policy reaction also caused the world wheat price to increase by $16.8 \%$ rather than $10 \%$. In the second scenario, countries that are net wheat importers implemented import taxes (import subsidies are forbidden) such that the real domestic wheat price remained constant (the domestic price is not constant if the strategic rigidity-i.e., no import subsidies-is binding). Import duties are decreased by between 13 and $30 \%$ age points, and the world price of wheat increased by $12.6 \%$. If both policy reactions are allowed (increasing export taxes and reducing import duties without implementing import subsidies), additional export taxes between 19 and $50 \%$ were implemented, and the world price of wheat increased by $20.6 \%$ : implementing these trade policies caused the world price to more than double.

Concerning countries' national real income, net wheat exporters' economic welfare is positively affected by the initial shock and their policy response (increasing export taxes), while that of net wheat importers' welfare is negatively affected. The economic welfare of Argentina as well as those of Australia, Canada, and Ukraine significantly increased under all shocks, in particular under the shock that combines endogenous export taxes and import tariffs. On the other hand, net wheat importers, such as Egypt and Eastern Africa, are significantly hurt by these shocks in terms of real income.

This collective action problem necessitates an institutional response: the next section examines to what extent the WTO may provide a framework adapted to discipline these inefficient trade policies.

\footnotetext{
${ }^{2}$ In case of food glut on world markets, world prices are relatively low: in the model designed by Gouel (2014), import duties may be increased in the large food-importing country and export taxes may be decreased in the large food-exporting country since governments have also an objective of domestic price smoothing.

${ }^{3}$ The use of a dynamic version of MIRAGE could open the door for new analyses and new policy conclusions. In the long term, export restrictions diminish sector profitability and, as such, may decrease investment in these sectors. This means less supply in following periods of time with a potentially higher risk of increased domestic price which could lead local governments to implement new export restrictions. This increases the long-term cost of these policies with the extreme situation where a net-exporting country turns into a net-importing country.
} 


\subsection{Can Export Restrictions Be Disciplined in the WTO Framework?}

There is a clear trade-off between import duties and export taxes with a double asymmetry. First, in times of food crisis, export taxes are raised while import duties are reduced. Second, while increasing export taxes is clearly identified as a noncooperative policy, it is much more difficult to criticize a country when it reduces its import duties. However, both policy reactions have the same impact on world prices, and both policies hurt poor food-importing countries. While reducing import duties cannot be opposed from an institutional point of view, the policy reaction may be considered as a "beggar-thy-neighbor" policy when analyzed from an economic perspective.

The literature clearly reflects this dilemma. While Martin and Anderson (2012) and Bouët and Laborde (2012) underlined that reducing import duties also affects world price variability, Josling (2014) noted that "such impact ... [is] ... likely minor compared to the positive benefits for domestic consumers. Exporters ... [are] also benefiting from the reduction in protection levels and it would therefore not ... [make] sense to develop rules that ... [inhibit] countries from making increased use of imports when domestic prices are high" (Josling 2014, p. 6). On the contrary, Gouel (2014) concluded that "export restrictions do not play a more important role ... [in recent food price spikes] than tariffs. ... they both contribute to shift volatility to partners' markets" (Gouel 2014, p. 18). ${ }^{4}$

While the WTO gives its members total freedom to decrease import duties (even import subsidies are tolerated), the institution forbids the implementation of quantitative export restrictions (Article X1:1). However, international law makes an exception for temporary export quotas in times of critical shortages of food items (Article XI:2). Export taxes are not prohibited, but the WTO requires its members to consider how their export taxes will affect their trading partners and to notify when implementing export taxes.

Anania (2014) considered that the provisions concerning export restrictions, which was included in the agricultural "modalities" issued in December 2008, reflected a broad agreement on this issue and are not ambitious. He proposed modifying Article XI.2 by limiting the export prohibitions and restrictions which are allowed under Article XI to a certain time frame. He wrote: "Existing export prohibitions and restrictions in foodstuffs and feeds under Article XI.2 (a) of GATT 1994 shall be eliminated by the end of the first year of implementation" and "any new export prohibitions or restrictions under Article XI.2 (a) of GATT 1994 should not normally be longer than 12 months, and shall only be longer than 18 months with the agreement of the affected importing Members." He also highlighted the need to

\footnotetext{
${ }^{4}$ However, Gouel (2014) also concludes that export restrictions may be more damaging in the real world because of the asymmetry of world price distribution (commodity prices are positively skewed).
} 
strengthen the consultation and notification procedures so that they are performed within 90 days of introducing a new restrictive export measure.

Anania (2014) recommended two options, which he deemed realistic and can potentially be included in a low-ambition Doha Agreement. First, as proposed by many other observers, the commitment to shelter noncommercial interventions from export restrictions made by the G20 at the 2011 Cannes Summit ${ }^{5}$ needs to be transformed into a legal commitment at the WTO. Unfortunately, at the 2011 WTO Ministerial Conference in Geneva, the proposal ${ }^{6}$ to adopt this approach at a multilateral level was opposed by key countries including Argentina, Brazil, China, India, and South Africa ${ }^{7}$, which are all G20 members. And without a consensus, the proposal was not adopted. Even though it is not legally binding, a statement made during a Ministerial Conference would have been the first step toward the inclusion of this basic requirement in the final Doha package-avoiding export restrictions because they adversely affect food aid. Indeed, food purchases by international organizations concern mainly key staple products and a few processed products for emergency reasons. ${ }^{8}$ They represent a limited amount of total worldwide traded quantities of these food items. Second, making existing disciplines enforceable essentially involves clarifying the definition of the conditions under which export quantitative restrictions are allowed. The exact wording of Article XI is imprecise: "temporarily applied to prevent or relieve critical shortages of foodstuffs or other products essential to the exporting contracting party" (Article XI:2a of GATT 1994). In particular, the words "temporarily" and "critical" need to be clearly defined. However bringing discipline into the area of export restrictions is a complex issue.

Cardwell and Kerr (2014) adopted a pessimistic view on this issue. They opined that any disciplinary measures to deal with export taxes would neither be effective nor have any deterrent effects. Trade disputes, including export restrictions, occur over a different time frame than the other disputes. Any disputes arising from export restrictions during a period of high food prices are unlikely to be resolved before the prohibited restriction is lifted. Moreover, the authors also believed that retaliatory

\footnotetext{
5"According to the Action Plan, we agree to remove food export restrictions or extraordinary taxes for food purchased for noncommercial humanitarian purposes by the World Food Program and agree not to impose them in the future." G20 Cannes Summit, 3-4 November 2011. This commitment was based on the G20 Action Plan defined on 23 June 2011 and was based on Recommendation \#5 from the international organizations report for the G20 on "Price volatility in food and agricultural markets: policy responses." Available at http://www.amis-outlook.org/fileadmin/ templates/AMIS/documents/Interagency_Report_to_the_G20_on_Food_Price_Volatility.pdf.

${ }^{6}$ The proposal was supported by Australia, Canada, Chile, Costa Rica, the European Union, Korea, Indonesia, Japan, Mexico, Norway, Saudi Arabia, Singapore, Switzerland, and Turkey.

${ }^{7}$ See Bridges, Volume 15-number 37. Available at http://ictsd.org/i/news/bridgesweekly/117348.

${ }^{8}$ For instance, the World Food Program, in 2013, procured mainly rice, maize, wheat, wheat flour, pulses, vegetable oil, sorghum, maize meal, sugar, and blended food. The latter includes pasta, high-energy biscuits, emergency rations, and ready-to-use supplementary foods (breast milk supplement)(see http://documents.wfp.org/stellent/groups/public/documents/ communications/wfp264134.pdf).
} 
measures are difficult to design; retaliation for an export restriction in a particular sector should be carried out in another sector, and the retaliation should amount to the same value as the lost exports. This is likely difficult to implement when there is great disparity between the countries concerned, such as in the case of trade between poor net food-importing countries and countries having imposed export restrictions.

\subsection{Concluding Remarks: Looking for a Solution}

As discussed in Sect. 8.2, export restrictions play an important role in increasing price volatility and magnifying the impact of natural weather variability on agricultural markets. It greatly contributes to policy uncertainty and therefore undermines private investments in domestic agricultural supply, and in trade-related infrastructure and network. The binding process of import tariffs at the WTO was particularly aimed at reducing this policy instability, creating a more secure environment for the private sector and fostering investments. At the same time, it limits the possibility of a retaliation and prevents noncooperative outcomes and the so-called trade wars from emerging. ${ }^{9}$ However, the current system is quite asymmetric at the WTO, as mentioned in Sect. 8.3, while import restrictions are severely dealt with by a set of disciplinary measures, export restrictions do not face the same constraints. On the import side, a clear framework is provided by the binding of tariffs (100\% in agriculture); tariffication and elimination of quantitative import restrictions (GATT article XI), exceptional conditions notwithstanding; and stringent rules framing the use of contingent protection (antidumping duties in GATT article 6, safeguards GATT article 19, etc.). On the export side, only quantitative export restrictions are currently disciplined, and the policy space to use them remains large, especially for food products. Because supplier countries do not face similar disciplines, this asymmetry undermines the pursuit of global integration of agricultural markets, and it strengthens the arguments of countries that do not want to reduce their tariffs and increase their reliance on world markets. Indeed, the current framework provides an unbalanced distribution of risks between importers and exporters, and it also lets suppliers increase their market power. It could potentially even have worse consequences: the overall price instability and the asymmetry in disciplinary measures could lead to the relaxation of disciplinary actions against contingent

\footnotetext{
${ }^{9}$ In fact, applying the game theory to trade policy leads to the conclusion that to facilitate the emergence of cooperation, there is a choice of either institutionalizing a discipline that forbids noncooperation (a world institution that forbids countries to implement beggar-thy-neighbor trade policies) or allowing countries to use retaliatory measures to prevent other countries from being noncooperative. The threat of retaliation is viewed as a powerful means of encouraging cooperation (see Axelrod 1981; Bouët 1992). The reality of the trading system today lies somewhere between these two options since the WTO forbids the use of some policy instruments (import duties) but authorizes the use of others (export restrictions). Moreover, a global institution is necessary since trading partners differ in size and capacity to hurt other countries.
} 
import measures, as with the special safeguard mechanism introduced by the G-33, instead of strengthening regulations on contingent export restrictions.

In this context, it is important to discuss potential solutions by means of new WTO regulations or experimenting with new concepts found in some bilateral agreements. Indeed, the elimination of export restrictions can be seen as a firstbest solution, but domestic political economy will make it unrealistic to attain such outcome in the short run, especially for countries with weak institutions. This is because these countries will need time to reform their tax system to replace export taxes by production taxes.

If not at the multilateral level, a solution may be reached at least on a plurilateral basis. ${ }^{10}$ Looking at recent bilateral agreements reveals that some of these features are already included in both North-North and North-South deals. As an example of a North-North deal, the Comprehensive Trade and Economic Agreement (CETA) between the EU and Canada states its position on restrictive trade policies in certain terms; Article 7 of the agreement eliminates duties and taxes on exports: "Neither Party may maintain or institute any duties, taxes or other fees and charges imposed on, or in connection with, the exportation of goods to the other Party, or any internal taxes or fees and charges on goods exported to the other Party, that are in excess of those that would be imposed on those goods when destined for internal sale." The Dominican Republic-Central America Free Trade Agreement (CAFTA-DR) is a free trade agreement between the USA, five Central American countries, and the Dominican Republic. The agreement's key principle is to bind existing measures, granting them a "grandfathering" clause, and ban new export taxes (export bans are still subject to Article XI of the GATT); Article 3.8 of the agreement states: " [ . . . ]no Party may adopt or maintain any prohibition or restriction on [...] the exportation or sale for export of any good destined for the territory of another Party, except in accordance with Article XI of the GATT 1994." Article 3.11 indicates clearly that discriminatory practices are banned: "Export Taxes Except as provided in Annex 3.11, no Party may adopt or maintain any duty, tax, or other charge on the export of any good to the territory of another Party, unless such duty, tax, or charge is adopted or maintained on any such good: (a) when exported to the territories of all other Parties; and (b) when destined for domestic consumption."

The Economic Partnership Agreement, negotiated between the EU and some members of the Southern African Development Community (2015), also expresses its position in firm language while still maintaining some flexibility for the lessadvanced economies. Article 26.1 follows the binding approach: "No new customs duties or taxes imposed on or in connection with the exportation of goods shall be introduced, nor shall those already applied be increased, in the trade between the

\footnotetext{
${ }^{10}$ If a plurilateral approach on all commodities is not achievable, a commodity-by-commodity approach following the sectoral initiatives could be considered. The main limit is that for most of the key staple commodities, one of the major exporters is very defensive regarding export taxes regulations (e.g., Russia, Argentina, and India on wheat).
} 
Parties from the date of entry into force of this Agreement, except as otherwise provided for in this Article." Article 26:2 recognizes that "In exceptional circumstances, $[\ldots]$ where essential for the prevention or relief of critical general or local shortages of foodstuffs or other products essential to ensure food security Botswana, Lesotho, Namibia, Mozambique and Swaziland may introduce, after consultation with the EU, temporary customs duties or taxes imposed on or in connection with the exportation of goods, on a limited number of additional products." So, in this agreement, the largest economies (South Africa, the EU) have strong commitments to fulfill, while the others benefit from a special and differentiated treatment. Sections 6-10 of Article 26 provide an interesting framework for how to prevent products exempted from export taxes from being reexported to third parties on a bilateral basis.

So, what can be done, especially in the context of restricting contingent, short-term export restrictions? As previously discussed, humanitarian interventions should be shielded from these measures in any basic WTO decisions, but attempts to change international laws have faced strong opposition. In this context, the first basic step is to enforce a strong monitoring and notifications process, ${ }^{11}$ aimed at reducing asymmetry of information. To keep both private and public agents informed, there are ongoing efforts to create agricultural market information systems aimed at providing updated policy changes for key agricultural commodities not only at the WTO but also at the G20, with its AMIS initiative. ${ }^{12}$ However, the lack of automatic sanctions when countries fail to notify, which is a larger issue facing the WTO than export restrictions, is still a major problem. The second step is to develop a system that focuses on protecting small and vulnerable economies (SVEs). SVEs are generally more open and have lower income, poorer consumers, and no capacity to retaliate. Also, their demand, even when aggregated, cannot be considered as a major driver of global price increase. To ensure healthy global trade, protecting these countries and limiting negative externalities coming from other larger countries should be prioritized.

A natural way to address this issue is the "reversed" tariff quota approach. For normal import levels (e.g., the average bilateral import volume in the last 3 years), SVEs should be able to import food products without quantitative restrictions and additional export taxes. This would guarantee normal market access conditions even when world market turmoil causes major traders to change their policies. Beyond the "historical" level of imports, exporters would be free to apply shortterm restrictions.

\footnotetext{
${ }^{11}$ This issue was emphasized in the WTO agricultural committee meeting on 21 June 2011: "These require the restricting country to take into account the impact on importing countries' food security, to notify the WTO as soon as possible, and as far in advance as possible, to be prepared to discuss the restriction with importing countries and to supply them with detailed information when asked for it."

${ }^{12} \mathrm{http} / / / \mathrm{www}$. amis-outlook.org/home/en/
} 
Another solution is to replace rigid legislation by a price mechanism and to apply a Pigouvian tax on the negative externalities of short-term surges in export restrictions. When a country, at least a G20 country, implements a new export restriction on food products, it would have to pay a fee. If more sophisticated pricing rules can be developed, a first approximation could be the historical amount of taxes collected from goods imported by an SVE from this exporter. The automaticity of the payment is ensured by the effective revenue collected by the exporting countries $^{13}$ and will address the key problems of (1) a lengthy dispute settlement at the WTO and (2) the lack of retaliation capacity by the SVE. The income generated through collecting this fee could be directly channeled toward helping SVEs pay their surging food import bills and fund their emergency safety nets. Alternatively, the income could also be used to provide the World Food Program with extra resources so that the program can cope with an increase in world food prices and develop targeted interventions. Similarly, a market for authorizing quantitative restrictions (like the "permits to pollute") can allow exporters to restrict their export quantities, while SVEs would have "importing rights" calculated based on historical import levels and could sell these licenses to exporters, thereby generating income to cover their import bills. These different measures are designed to provide an international insurance mechanism against harmful policies by reducing incentives to implement them (additional costs to exporters) and providing remedies for the most vulnerable countries.

Open Access This chapter is distributed under the terms of the Creative Commons AttributionNoncommercial 2.5 License (http://creativecommons.org/licenses/by-nc/2.5/) which permits any noncommercial use, distribution, and reproduction in any medium, provided the original author(s) and source are credited.

The images or other third party material in this chapter are included in the work's Creative Commons license, unless indicated otherwise in the credit line; if such material is not included in the work's Creative Commons license and the respective action is not permitted by statutory regulation, users will need to obtain permission from the license holder to duplicate, adapt or reproduce the material.

\section{References}

Amiruddin MN (2003) Palm oil products exports, prices and export duties: Malaysia and Indonesia compared. Oil Palm Ind Econ J 3(2): 15-20

Anania G (2014) Export restrictions and food security. In: Melendez-Ortiz R, Bellmann C, Hepburn J (eds) Tackling agriculture in the post-Bali context. ICTSD, Geneva

Axelrod R (1981) The evolution of cooperation. Basic Books, New York

Bickerdike CF (1906) The theory of incipient taxes. Econ J 16:529-535

Bouët A (1992) Représailles et Commerce International Stratégique. Economica, Paris

Bouët A, Laborde D (2012) Food crisis and export taxation: the cost of non-cooperative trade policies. Rev World Econ 148(1):209-233

\footnotetext{
${ }^{13}$ For short-run export taxes during an episode of high price volatility, tax revenue is rarely the main objective of a government applying such measures.
} 
Bouët A, Estrades C, Laborde D (2014) Differential export taxes along the oilseeds value chain: a partial equilibrium analysis. Am J Agric Econ 96(3):924-938

Cardwell R, Kerr WA (2014) Can export restrictions be disciplined through the world trade organization? World Econ 37(8):1186-1196

Crosby D (2008) WTO legal status and evolving practice of export taxes. Bridges 12(5)

Diamond PA (1975) A many-person Ramsey rule. J Public Econ 4:335-342

Gouel C (2014) Trade policy coordination and food price volatility. CEPII Working Paper 2014-23

Johnson HG (1953) Optimum tariffs and retaliation. Rev Econ Stud 21:142-153

Josling T (2014) The WTO, food security and the problem of collective action. In: Paper presented at the World Bank seminar on Food Security

Laborde D, Estrades C, Bouët A (2013) A global assessment of the economic effects of export taxes. World Econ 36(10): 1333-1354

Martin W, Anderson K (2012) Export restrictions and price insulation during commodity price booms. Am J Agric Econ 94(2):422-427

Piermartini R (2004) The role of export taxes in the field of primary commodities. WTO Discussion Paper. World Trade Organization, Geneva

Ramsey FP (1927) A contribution to the theory of taxation. Econ J 37:47-61

Rodriguez C (1974) The non-equivalence of tariffs and quotas under retaliation. J Int Econ 4:295298

Tower E (1975) The optimum quota and retaliation. Rev Econ Stud 42(4):623-630

World Bank (1998) Indonesia, strengthening forest conservation. World Bank, Washington, DC 